\title{
Curtain color and lighting program in broiler production: II. carcass and parts yield and abdominal fat deposition
}

\author{
Valéria Maria Nascimento Abreu ${ }^{1}$, Paulo Giovanni de Abreu ${ }^{1}$, Arlei Coldebella ${ }^{1}$, Fátima \\ Regina Ferreira Jaenisch ${ }^{1}$, Doralice Pedroso de Paiva ${ }^{1}$
}

${ }^{1}$ Embrapa Suínos e Aves, Br 153, Km 110, Caixa Postal 21 - 89700-000, Concórdia, Santa Catarina, Brazil.

ABSTRACT - The objective of the present study was to evaluate carcass and parts' yield, abdominal fat deposition and breast and foot pad blisters of broilers reared under two lighting programs (nearly continuous or intermittent) in broilers houses with yellow and blue curtains. The experiment was conducted between June, 2004 and May, 2005. Six flocks were sequentially housed in four $12 \times 10 \mathrm{~m}$ broiler houses divided into 4 pens with 200 birds each. The litter was reused six times or until flock 6. A completely randomized design in a $6 \times 2 \times 2$ factorial arrangement (flocks, lighting programs, curtains) with four replicates per treatment was applied. A total of 288 birds were evaluated for carcass yield. Curtain color did not affect carcass or parts' yield. The effect of lighting program and curtain color on carcass yield may depend on other factors related to flock. Intermittent lighting program promoted the highest drumstick and thigh yields. Lighting programs and curtain colors did not affect abdominal fat deposition or the presence of breast and foot pad blisters.

Key Words: breast blister, breast yield, foot pad blister, intermittent, leg yield, nearly continuous

\section{Introduction}

Understanding the influence of photoperiod on broiler production allows producers to select the best lighting program and make decisions to optimize the combination of production characteristics that bring higher profits. Long duration lighting programs (24 hours of light) may have beneficial effects on breast yield, but increase leg problems in broilers. Intermittent lighting programs (23 hours of light and 1 hour of darkness or 16 hours of light and 8 of darkness) are characterized by repeated light and dark periods within 24 hours. Broilers submitted to intermittent lighting program show higher productivity and fewer leg problems when compared to those reared under continuous lighting programs (Classen, 1996). According to Renden et al. (1991), despite the large number of studies on lighting programs, there is still little information on their effect on carcass yield or quality. Moraes (2006), when studying the effect of lighting programs on parts yields, did not find any influence on the carcass yield of broilers slaughtered at 45 days of age, but those submitted to 23 daily hours of light presented higher breast yield, as reported by Renden et al. (1992), Renden et al. (1993) and Renden et al. (1994), who also observed higher breast yield in 49-day-old broilers submitted to a program of 23 hours of light relative to a program of 16 hours of light. However, in other studies, Renden et al. (1991) and Renden et al. (1996) did not find any influence of lighting programs on breast yield. It must be mentioned that carcass parts' yields and abdominal fat contents found by Renden et al. (1991), Renden et al.(1992), Renden et al. (1993), Renden et al. (1994), Renden et al. (1996) and Moraes (2006) are very different.

In addition to lighting programs, another issue that is much discussed in broiler production is the use of blue or yellow curtains in open-sided poultry houses. There is little scientific information on this subject, and recommendations are based on assumptions of the beneficial effects of the use of these materials.

Therefore, the objective of this study was to evaluate carcass and parts' yield, abdominal fat deposition, and the incidence of breast and foot pad blisters of broilers submitted to two different lighting programs (nearly continuous and intermittent) and reared in open-sided broiler houses with yellow or blue curtains.

\section{Material and Methods}

This experiment was carried out at Embrapa Suínos e Aves, Brazil, between June 24, 2004 and May 12, 2005. Six consecutive broiler flocks were reared in four broiler houses measuring $12 \mathrm{~m} \times 10 \mathrm{~m}$, internally divided in four pens, each one housing 200 birds.

A total of 19,200 Ross males were distributed according to a completely randomized experimental design in a $6 \times 2 \times 2$ 
factorial arrangement (flocks, lighting programs and curtains), with four replicates per treatment.

The first flock was housed on a new litter, which was reused by the subsequent flocks. Litter was replaced only in the brooding area. Light was provided by $60 \mathrm{~W}$ incandescent light bulbs.

The effects of color curtain (blue or yellow) and lighting program (nearly continuous: 23L:1D; intermittent: 16L:2D + $1 \mathrm{~L}+2 \mathrm{D}$, where $\mathrm{L}=$ hours of light and $\mathrm{D}=$ hours of darkness) were evaluated as follows: house 1 = blue curtain and intermittent light; house 2 = yellow curtain and intermittent light; house 3 = yellow curtain and nearly continuous light; house 4 = blue curtain and nearly continuous light.

Carcass yield was evaluated by removing from each pen, three birds whose body weight was as close as possible to pen average, totaling 288 birds. Birds were duly identified and sacrificed, and slaughter weight, eviscerated carcass weight, cuts weights, and abdominal fat weight (bound to the abdominal wall) were determined. The incidence of breast and foot pad blisters was visually scored in $20 \%$ of the broilers (40 per pen) in the third week after housing and at slaughter using a 1-5 subjective scale (1 = absence of lesions and $5=$ high incidence of lesions).

Data were submitted to analysis of variance using the GLM procedure of SAS statistical package (2003), considering the effects of flock, lighting program, curtain color, and their interactions.

\section{Results and Discussion}

Flock significantly influenced $(\mathrm{P}<0.0001)$ carcass, wing, drumstick, thighs, breast, back, and abdominal fat yields. There was a significant effect $(\mathrm{P}<0.05)$ of flock $\times$ lighting program $\times$ curtain color interaction on carcass and back yields. Significant differences $(\mathrm{P}<0.05)$ between the applied lighting programs were observed only in drumstick and thighs' yields. The other parameters were not affected by lighting program. Also, there was no effect of curtain color $(\mathrm{P}>0.05)$ on none of the evaluated parameters (Table 1).
When the effect of the interaction flock $\times$ lighting program $\times$ curtain on carcass yield was evaluated (Table 2 ), significant effects of lighting program within curtain or of curtain color within lighting program were observed only in flocks 1 and 4. Flock 1's broilers reared in houses with blue curtain presented higher carcass yield when submitted to the intermittent lighting program. In flock 4, the lowest carcass yields were obtained with intermittent lighting program in houses with yellow curtain. These results indicated that the effect of lighting program and curtain color on carcass yield may depend on another factor related to flock, which was not evaluated in the present study.

Wing and breast yields were not influenced by lighting program or by curtain color. On the other hand, drumstick and thighs yields (Figure 1) were better when the intermittent lighting program was applied, regardless of curtain color, and were only influenced by that factor. These results are opposed to the findings of Moraes (2006), who obtained higher drumstick + thighs' yield with a program of 23 hours of light than the program of 16 hours of light and natural lighting. However, Renden et al. (1991), Renden et al. (1992), Renden et al. (1993) and Renden et al. (1994) did not observe any effect of the lighting program on drumstick yield, but in a subsequent study, Renden et al. (1996) concluded that broilers reared under a lighting program of 16 hours of light presented higher drumstick yield when compared to those reared under 23 hours of light, daily.

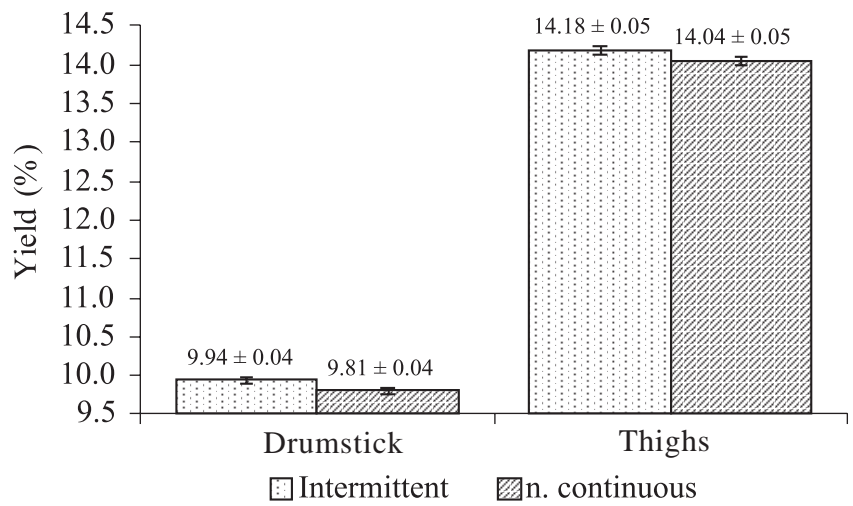

Figure 1 - Drumstick and thighs’ yield.

Table 1 - Analysis of variance of carcass, parts and abdominal fat yields

\begin{tabular}{|c|c|c|c|c|c|c|c|c|}
\hline Source & $\mathrm{DF}^{1}$ & Carcass & Wing & Drumstick & Thighs & Breast & Back & Abdominal fat \\
\hline Flock & 5 & $<0.0001$ & $<0.0001$ & $<0.0001$ & $<0.0001$ & $<0.0001$ & $<0.0001$ & 0.0757 \\
\hline Light & 1 & 0.0864 & 0.2793 & 0.0255 & 0.0440 & 0.5836 & 0.2106 & 0.8449 \\
\hline Flock $\times$ light & 5 & 0.4494 & 0.9227 & 0.9413 & 0.6604 & 0.2210 & 0.6716 & 0.9632 \\
\hline Curtain & 1 & 0.1061 & 0.1720 & 0.8090 & 0.2199 & 0.2569 & 0.7247 & 0.2937 \\
\hline Flock $\times$ curtain & 5 & 0.7648 & 0.4814 & 0.8900 & 0.8960 & 0.5777 & 0.4484 & 0.5202 \\
\hline Light $\times$ curtain & 1 & 0.8523 & 0.4640 & 0.1875 & 0.6656 & 0.2110 & 0.6025 & 0.3761 \\
\hline Flock $\times$ light $\times$ curtain & 5 & 0.0414 & 0.1157 & 0.0723 & 0.0567 & 0.1049 & 0.0190 & 0.6434 \\
\hline
\end{tabular}

${ }^{1}$ Degrees of freedom. 
Table 2 - Average yield (\%) of carcass, parts and abdominal fat, as a function of flock, lighting program and curtain color

\begin{tabular}{|c|c|c|c|c|}
\hline \multirow[t]{2}{*}{ Part } & \multirow[t]{2}{*}{ Lighting program } & \multicolumn{2}{|c|}{ Curtain color } & \multirow[t]{2}{*}{ Mean } \\
\hline & & Yellow & Blue & \\
\hline & \multicolumn{4}{|c|}{ Period $1(6 / 24$ to $8 / 05 / 2004)$} \\
\hline \multirow[t]{3}{*}{ Carcass } & Intermittent & $74.92 \mathrm{aA}$ & 75.39aA & 75.15 \\
\hline & Nearly continuous & $74.42 \mathrm{aA}$ & 73.97aB & 74.20 \\
\hline & Mean & 74.67 & 74.68 & \\
\hline \multirow[t]{3}{*}{ Wing } & Intermittent & 7.62 & 7.70 & 7.66 \\
\hline & Nearly continuous & 7.51 & 7.51 & 7.55 \\
\hline & Mean & 7.56 & 7.60 & \\
\hline \multirow[t]{3}{*}{ Drumstick } & Intermittent & 9.96 & 10.05 & $10.00 \mathrm{~A}$ \\
\hline & Nearly continuous & 9.76 & 9.96 & 9.86B \\
\hline & Mean & 9.86 & 10.00 & \\
\hline \multirow[t]{3}{*}{ Thighs } & Intermittent & $14.29 \mathrm{~A}$ & 13.89B & 14.09 \\
\hline & Nearly continuous & $14.03 \mathrm{~B}$ & $13.91 \mathrm{~A}$ & 13.97 \\
\hline & Mean & 14.16 & 13.90 & \\
\hline \multirow[t]{3}{*}{ Breast } & Intermittent & 23.79 & 24.58 & 24.18 \\
\hline & Nearly continuous & 23.79 & 23.39 & 23.59 \\
\hline & Mean & 23.79 & 23.98 & \\
\hline \multirow[t]{3}{*}{ Back } & Intermittent & 17.54 & 17.81 & 17.68 \\
\hline & Nearly continuous & $17.66 \mathrm{bA}$ & $17.74 \mathrm{aA}$ & 17.70 \\
\hline & Mean & 17.60bA & $17.77 \mathrm{aA}$ & \\
\hline \multirow[t]{4}{*}{ Abdominal fat } & Intermittent & 1.52 & 1.27 & 1.40 \\
\hline & Nearly continuous & 1.51 & 1.41 & 1.46 \\
\hline & Mean & 1.51 & 1.34 & \\
\hline & \multicolumn{4}{|c|}{ Period 2 (8/19 to $9 / 30 / 2004)$} \\
\hline \multirow[t]{3}{*}{ Carcass } & Intermittent & 75.16 & 74.00 & 74.58 \\
\hline & Nearly continuous & 74.36 & 74.33 & 74.35 \\
\hline & Mean & 74.76 & 74.16 & \\
\hline \multirow[t]{3}{*}{ Wing } & Intermittent & 7.45 & 7.42 & 7.44 \\
\hline & Nearly continuous & 7.36 & 7.48 & 7.42 \\
\hline & Mean & 7.40 & 7.45 & \\
\hline \multirow[t]{3}{*}{ Drumstick } & Intermittent & 9.67 & 9.58 & $9.63 \mathrm{~A}$ \\
\hline & Nearly continuous & 9.54 & 9.52 & $9.53 \mathrm{~B}$ \\
\hline & Mean & 9.60 & 9.55 & \\
\hline Thighs & Intermittent & 14.21 & 14.08 & $14.15 \mathrm{~A}$ \\
\hline & Nearly continuous & 13.98 & 13.94 & 13.96B \\
\hline & Mean & 14.09 & 14.01 & \\
\hline Breast & Intermittent & 22.76 & 22.60 & 22.68 \\
\hline & Nearly continuous & 22.43 & 22.52 & 22.48 \\
\hline & Mean & 22.59 & 22.56 & \\
\hline Back & Intermittent & 16.86 & 16.60 & 16.73 \\
\hline & Nearly continuous & 16.79 & 16.59 & 16.69 \\
\hline & Mean & 16.82 & 16.59 & \\
\hline Abdominal fat & Intermittent & 1.67 & 1.58 & 1.63 \\
\hline & Nearly continuous & 1.63 & 1.61 & 1.62 \\
\hline & Mean & 1.65 & 1.59 & \\
\hline & Period 3 & (10/14 to 1 & 5/2004) & \\
\hline Carcass & Intermittent & 72.86 & 72.36 & 72.66 \\
\hline & Nearly continuous & 71.95 & 72.16 & 72.05 \\
\hline & Mean & 72.40 & 72.26 & \\
\hline Wing & Intermittent & 7.20 & 7.35 & 7.28 \\
\hline & Nearly continuous & 7.14 & 7.40 & 7.27 \\
\hline & Mean & 7.17 & 7.37 & \\
\hline Drumstick & Intermittent & 9.99 & 9.84 & $9.92 \mathrm{~A}$ \\
\hline & Nearly continuous & 9.69 & 9.79 & $9.74 \mathrm{~B}$ \\
\hline & Mean & 9.84 & 9.81 & \\
\hline Thighs & Intermittent & 13.87 & 13.87 & $13.87 \mathrm{~A}$ \\
\hline & Nearly continuous & 13.56 & 13.59 & 13.58B \\
\hline & Mean & 13.71 & 13.73 & \\
\hline Breast & Intermittent & 22.24 & 22.20 & 22.22 \\
\hline & Nearly continuous & 22.70 & 22.13 & 22.42 \\
\hline & Mean & 22.47 & 22.16 & \\
\hline
\end{tabular}

Cont. Table 2

\begin{tabular}{|c|c|c|c|c|}
\hline \multirow[t]{2}{*}{ Part } & \multirow[t]{2}{*}{ Lighting program } & \multicolumn{2}{|c|}{ Curtain color } & \multirow[t]{2}{*}{ Mean } \\
\hline & & Yellow & Blue & \\
\hline \multirow[t]{3}{*}{ Back } & Intermittent & 15.78 & 15.69 & 15.74 \\
\hline & Nearly continuous & 15.50 & 15.81 & 15.66 \\
\hline & Mean & 15.64 & 15.75 & \\
\hline \multirow[t]{4}{*}{ Abdominal fat } & Intermittent & 1.61 & 1.39 & 1.50 \\
\hline & Nearly continuous & 1.53 & 1.35 & 1.44 \\
\hline & Mean & 1.57 & 1.37 & \\
\hline & \multicolumn{3}{|c|}{ Period $4(12 / 09 / 2004$ to $01 / 20 / 2005)$} & \\
\hline \multirow[t]{3}{*}{ Carcass } & Intermittent & $74.85 \mathrm{bB}$ & $76.26 \mathrm{aA}$ & 75.56 \\
\hline & Nearly continuous & 76.61aA & 75.32aA & 75.97 \\
\hline & Mean & 75.73 & 75.79 & \\
\hline \multirow[t]{3}{*}{ Wing } & Intermittent & 7.52 & 7.73 & 7.63 \\
\hline & Nearly continuous & 7.67 & 7.58 & 7.63 \\
\hline & Mean & 7.59 & 7.65 & \\
\hline \multirow[t]{3}{*}{ Drumstick } & Intermittent & 9.83 & 9.98 & $9.91 \mathrm{~A}$ \\
\hline & Nearly continuous & 9.91 & 9.72 & $9.82 \mathrm{~B}$ \\
\hline & Mean & 9.87 & 9.85 & \\
\hline \multirow[t]{3}{*}{ Thighs } & Intermittent & 14.61 & 14.83 & $14.72 \mathrm{~A}$ \\
\hline & Nearly continuous & 14.86 & 14.47 & 14.67B \\
\hline & Mean & 14.73 & 14.65 & \\
\hline \multirow[t]{3}{*}{ Breast } & Intermittent & 22.41 & 23.00 & 22.71 \\
\hline & Nearly continuous & 23.27 & 22.89 & 23.08 \\
\hline & Mean & 22.84 & 22.94 & \\
\hline \multirow{3}{*}{ Back } & Intermittent & $17.24 \mathrm{bB}$ & $17.73 \mathrm{aA}$ & 17.49 \\
\hline & Nearly continuous & $17.51 \mathrm{aA}$ & 17.37bB & 17.44 \\
\hline & Mean & 17.37 & 17.55 & \\
\hline \multirow[t]{4}{*}{ Abdominal fat } & Intermittent & 1.35 & 1.35 & 1.35 \\
\hline & Nearly continuous & 1.38 & 1.38 & 1.38 \\
\hline & Mean & 1.36 & 1.36 & \\
\hline & Period 5 & $02 / 03$ to 0 & 7/2005) & \\
\hline Carcass & Intermittent & 74.97 & 73.90 & 74.44 \\
\hline & Nearly continuous & 73.70 & 73.74 & 73.72 \\
\hline & Mean & 74.33 & 73.82 & \\
\hline Wing & Intermittent & 7.73 & 7.53 & 7.63 \\
\hline & Nearly continuous & 7.47 & 7.62 & 7.55 \\
\hline & Mean & 7.60 & 7.57 & \\
\hline Drumstick & Intermittent & 10.09 & 9.60 & $9.85 \mathrm{~A}$ \\
\hline & Nearly continuous & 9.40 & 9.81 & $9.61 \mathrm{~B}$ \\
\hline & Mean & 9.74 & 9.70 & \\
\hline Thighs & Intermittent & 14.26 & 14.33 & $14.30 \mathrm{~A}$ \\
\hline & Nearly continuous & 14.16 & 13.92 & $14.04 \mathrm{~B}$ \\
\hline & Mean & 14.21 & 14.12 & \\
\hline Breast & Intermittent & 21.75 & 21.88 & 21.82 \\
\hline & Nearly continuous & 22.66 & 21.93 & 22.30 \\
\hline & Mean & 22.20 & 21.90 & \\
\hline Back & Intermittent & 17.85 & 17.15 & 17.50 \\
\hline & Nearly continuous & 16.95 & 17.16 & 17.06 \\
\hline & Mean & 17.40 & 17.15 & \\
\hline Abdominal fat & Intermittent & 1.35 & 1.47 & 1.41 \\
\hline & Nearly continuous & 1.42 & 1.38 & 1.40 \\
\hline & Mean & 1.38 & 1.42 & \\
\hline & Period 6 & $03 / 31$ to 0 & 2/2005) & \\
\hline Carcass & Intermittent & 73.73 & 72.32 & 73.03 \\
\hline & Nearly continuous & 73.07 & 72.82 & 72.95 \\
\hline & Mean & 73.40 & 72.57 & \\
\hline Wing & Intermittent & 7.69 & 7.63 & 7.66 \\
\hline & Nearly continuous & 7.59 & 7.68 & 7.64 \\
\hline & Mean & 7.64 & 7.65 & \\
\hline Drumstick & Intermittent & 10.36 & 10.31 & $10.34 \mathrm{~A}$ \\
\hline & Nearly continuous & 10.34 & 10.22 & $10.28 \mathrm{~B}$ \\
\hline & Mean & 10.35 & 10.26 & \\
\hline Thighs & Intermittent & 14.19 & 13.75 & $13.97 \mathrm{~A}$ \\
\hline & Nearly continuous & 13.83 & 14.25 & $14.04 \mathrm{~A}$ \\
\hline & Mean & 14.01 & 14.00 & \\
\hline
\end{tabular}

R. Bras. Zootec., v.40, n.9, p.2035-2038, 2011 
Cont. Table 2

\begin{tabular}{llccc}
\hline Part & Lighting program & \multicolumn{2}{c}{ Curtain color } & \multirow{2}{*}{ Mean } \\
\cline { 3 - 4 } & & Yellow & Blue & \\
\hline \multirow{2}{*}{ Breast } & Intermittent & 23.05 & 21.84 & 22.45 \\
& Nearly continuous & 22.62 & 22.65 & 22.64 \\
& Mean & 22.83 & 22.24 & \\
Back & Intermittent & 17.16 & 17.53 & 17.35 \\
& Nearly continuous & 17.63 & 16.92 & 17.28 \\
\multirow{3}{*}{ Abdominal fat } & 17.39 & 17.22 & \\
& Mean & 1.59 & 1.44 & 1.52 \\
& Intermittent & 1.29 & 1.58 & 1.44 \\
& Nearly continuous & 1.44 & 1.51 & \\
\hline
\end{tabular}

Means followed by different small letters in the same row and different capital letters in the same column are different $(\mathrm{P} \leq 0.05)$ by $\mathrm{F}$ test.

There were no significant differences in abdominal fat yield, which demonstrates that fat deposition was not affected by the lighting programs. Renden et al. (1996) applied four different photoperiods: 1) 23L:1D; 2) 16L:8D; 3) 16L:3D1L:4D; 4) 16L:2D:1L:2D:1L:2D, where $\mathrm{L}=$ hours of light; and $\mathrm{D}=$ hours of darkness and did not find any influence of photoperiod on abdominal fat, wings, or thighs yields. However, Buyse et al. (1996), when evaluating abdominal fat deposition in broilers submitted to intermittent (1L:3E) or nearly continuous (23L:1E) lighting programs found that the intermittent lighting program reduced broiler abdominal fat deposition at 28 and 41 days of age. These authors concluded that adipose tissue deposition was postponed due to a change in the slope of the growth curve imposed by intermittent lighting. On the other hand, Ohtani \& Leeson (2000), when studying the effect of lighting program on abdominal fat, observed that abdominal fat accumulation was higher in broilers submitted to intermittent lighting program when compared to continuous lighting program.

In terms of carcass quality, in the six flocks, despite litter reuse, no breast or food pad blisters were observed, indicating that correct litter management is essential to prevent this type of lesion. These results are different from those obtained by Renden et al. (1992), who demonstrated that birds submitted to a program of 23 hours of light and $1 \mathrm{~h}$ of darkness presented fewer breast blisters, but more leg problems and broken collar bones. Breast blister are caused by the contact with the soil, which causes skin irritation. Those differences may be related to the fact that the broilers submitted to a lighting program of 16 hours of light and 8 of darkness spend longer periods in the dark, which allows resting. Renden et al. (1993) observed lower incidence of leg abnormalities in broilers reared under 14 hours of light and 10 hours of darkness if compared to those kept under 23 hours of light and 1 hour of darkness. Broilers submitted to continuous lighting program presented higher breast development, whereas those reared under 14 hours of light had better developed legs.

It is assumed in commercial poultry production that blue curtains promote a calmer environment, which may interfere in bird activity, favoring resting, and therefore, the development of breast blisters. However, the results of the present experiment do not confirm this assumption. The observed absence of breast and foot pad blisters demonstrated that curtain color and lighting program had no influence on this problem. Adequate litter management, removing clods and rotating the litter, seemed to be sufficient to keep broiler breasts and foot pads healthy.

\section{Conclusions}

Curtain color does not influence carcass or parts' yield, but intermittent lighting program results in higher drumstick and thighs' yield. Moreover, lighting program and curtain color do not affect abdominal fat deposition or the incidence of breast and foot pad blisters.

\section{References}

BUYSE, J.; SIMONS, P.C.M.; BOSHOUWERS, F.M.G. et al. Effect of intermittent lighting, light intensity and source on the performance and welfare of broilers. World's Poultry Science Journal, v.52, p.121-130, 1996.

CLASSEN, H.L. Principios sobre el manejo de luz em pollos de engorde, Avicultura Professional, v,14, n.2, p.21-27, 1996.

MORAES, D.T. Efeitos dos programas de luz sobre o desempenho, rendimentos de abate, aspectos econômicos e resposta imunológica em frangos de corte. 2006. 51f. Dissertação (Mestrado em Zootecnia) - Universidade Federal de Minas Gerais/Escola de Veterinária, Belo Horizonte.

OHTANI, S.; LEESON, S. The effect of intermittent lighting on metabolizable energy intake and heat production of male broilers. Poultry Science, v.79, p.167-171, 2000.

RENDEN, J.A.; BILGILI, S.F.; LIEN, R.J. et al. Live performance and yields of broilers provided various lighting schedules. Poultry Science, v.70, n.10, p.2055-2062, 1991.

RENDEN, J.A.; BILGILI, S.F.; KINCAID, S.A. Live performance and carcass yield of broiler strain crosses provided either sixteen or twenty-three hours of light per day. Poultry Science, v.71, n.9, p.1427-1435, 1992

RENDEN, J.A.; BILGILI, S.F.; KINCAID, S.A. Research note: Comparison of restricted and increasing light programs for male broiler performance and carcass yield. Poultry Science, v.72, n.2, p.378-382, 1993.

RENDEN, J.A.; MORAN, E.T.; KINCAID, S.A. Lack of interactions between dietary lysine or strain cross and photoschedule for male broiler performance and carcass yield. Poultry Science, v.73, n.11, p.1651-1662, 1994.

RENDEN, J.A.; MORAN JUNIOR, E.T.; KINCAID, S.A. Lighting programs for broilers that reduce leg problems without loss of performance or yield. Poultry Science, v.75, p.1345-1350, 1996.

STATISTICAL ANALYSES SYSTEM - SAS. System for Microsoft Windows: release 9,1. Cary: 2002-2003. (CD-ROM). 